\title{
Nomen Danielis numquam peribit ... Prof. PhDr. Daniel Škoviera, PhD. (30. november 1946, Mikulášová - 24. február 2021, Bratislava)
}

\author{
DOI: https://doi.org/10.24040/ahn.2021.24.01.143-144
}

Profesor Daniel Škoviera, klasický filológ, neolatinista, prekladatel' a popularizátor odkazu antiky, znalec a bádatel' humanizmu spätého s územím Slovenska, najmä však vynikajúci učitel', ktorý vychoval súčasnú generáciu slovenských klasických filológov a významne inšpiroval celý rad historikov raného novoveku. Bol najstarším synom gréckokatolíckeho kňaza Jána Škovieru (1914 - 2012), ktorý sa pre svoju vieru vedno so svojou rodinou stal terčom perzekúcií totalitného komunistického režimu. Tvorivý rozlet Daniela Škovieru bol utlmený v najlepších rokoch mladého vedca a vysokoškolského učitel'a - v roku 1979, pred získaním vedeckého osvedčenia candidatus scientiarum, ho prinútili vzdat' sa pôsobenia na mieste odborného asistenta na katedre klasickej a románskej filológie FF UK v Bratislave a stiahnut' sa do ústrania v pozícii knihovníka Kabinetu teórie a dejín žurnalistiky na tej istej fakulte. Toto vynútené otium mu však zároveň poskytlo priestor pre sústredenú prácu vedca a prekladatel'a. Po návrate na svoje pôvodné pracovisko v roku 1989 naplno zúročil roky práce „kabinetného učenca“ - v roku 1992 sa habilitoval prácou o slávnom bardejovskom humanistovi Leonardovi Stöckelovi (1510 - 1560). Stöckelov učitel' a priatel', humanista Valentinus Ecchius z Lindavy (1494 - 1556) bol druhou vel'kou témou Škovierovho vedeckého záujmu. Publikoval o ňom monografiu Bardejovčan Valentín Ecchius a jeho učebnica Ars versificandi (2002) a o ňom v roku 2004 predniesol aj svoju inauguračnú prednášku (Báseň o užitočnosti priatel'stva a svornosti od Valentína Ecchia). Ako profesor pôsobil na svojej Alma mater až do odchodu do dôchodku v roku 2018. Súčasne sa však angažoval aj pri založení Trnavskej univerzity v Trnave v roku 1992. Položil na nej základy pracoviska klasickej filológie, ktoré sa programovo zameralo na rozvíjanie novolatinských štúdií reprezentovaných aj vedeckým časopisom Sambucus a edíciou Scrinium Latino-Slovacum, ktoré uviedol do vedeckej komunity a sám v nich aj publikoval. Spomenút možno výber z diela menovaného Valentína Ecchia: Rozhovor o správe štátu - Útešný list - Náhrobné nápisy na pamiatku biskupa Jána Thurzu Báseň o užitočnosti priatel'stva a svornosti (2006), či edíciu promočnej tlače profesora historickej Trnavskej univerzity Jána Kaziho Stará a nová stoa (2009). Zásadný význam pre výskum humanizmu a renesancie spätého s územím Slovenska mala antológia Latinský humanizmus (2009), 
ktorú edične pripravil a sám do nej prispel prekladmi korešpondencie slovenských erazmovcov Mikuláša Oláha a Jána Antonína Košického so svojím majstrom, ako aj prekladmi d'alších diel V. Ecchia, L. Stöckela, alebo Trnavčana Jána Sambuca. Popri novolatinských štúdiách venoval vel'kú pozornost' aj ranokrest'anským prameňom a štúdiu ich jazykov. Viedol semináre z biblickej gréčtiny na Rímskokatolíckej bohosloveckej fakulte UK v Bratislave a na Teologickej fakulte TU v Trnave, spolupracoval na slovenskom ekumenickom preklade Biblie (1995 a 2007), založil edíciu Bibliotheca Antiqua Christiana, v rámci ktorej publikoval preklady viacerých diel sv. Bazila Vel'kého. Pri rekapitulácii jeho životného diela však nemožno opomenút' ani majstrovské preklady diel klasickej antiky - Ciceronove spisy $O$ rečníkovi a Rečník (1982), Ammianove Rímske dejiny (1988) či Plutarchove Životopisy slávnych Grékov a Rimanov (2008), ktorými sa zapísal aj do širšieho kultúrneho povedomia na Slovensku. Profesor Škoviera má na svojom konte viac ako pät’ stovák publikačných výstupov, okrem iného neúnavne písal, dnes neraz zaznávané, recenzie a glosy nových publikácií a ponúkal tak nielen mimoriadne cennú erudovanú reflexiu, ale aj nové podnety pre rozvoj svojej disciplíny. Hovorí sa, že po odchode človeka zostane prázdne miesto. V prípade Daniela Škovieru to však neplatí: ostalo po ňom nielen jeho celoživotné dielo - eruditio summa, ktoré podnecuje a vyzýva k d’alším výskumom, edíciám a prekladom diel slovenských humanistov, ale aj všetci tí, ktorí u neho študovali král'ovskú disciplínu humanitných vied - klasickú filológiu, a ktorým vštepil trvalú lásku k bonae litterae. Preto si na tomto mieste môžeme dovolit' parafrázovat' slová anglického humanistu Johna Coleta: „Nomen Danielis nunquam peribit, sed gloriae dabis nomen tuum sempiternae et sudans in Iesu vitam tibi comparabis illam aeternam."

Imrich Nagy 